\title{
$\longrightarrow_{\text {PSSR }}$ \\ Pakistan Social Sciences Review www.pssr.org.pk
}

\section{RESEARCH PAPER}

\section{Corruption and Fiscal Decentralization: A Comparative Analysis for Developed and Developing Economies}

\author{
Faiz Ur Rahim ${ }^{1}$ Rukhsana Parveen ${ }^{2}$
}

1. Assistant Professor, International Institute of Islamic Economics (IIIE), International Islamic University Islamabad, Pakistan

2. MS Economics Research Scholar, International Institute of Islamic Economics (IIIE), International Islamic University Islamabad, Pakistan

\begin{tabular}{|c|c|}
\hline IFO & \\
\hline $\begin{array}{l}\text { Rec } \\
\text { Marc } \\
\text { Acc } \\
\text { June } \\
\text { Onl }\end{array}$ & $\begin{array}{l}\text { Fiscal decentralization is thought to be a tool to control } \\
\text { corruption and improve governance in the economy. } \\
\text { Theoretical literature on fiscal federalism support this idea by } \\
\text { establishing the argument of more transparency in smaller } \\
\text { jurisdictions. The present study examines the impact of fiscal }\end{array}$ \\
\hline ion, & $\begin{array}{l}\text { decentralisation on the prevalence of corrup } \\
\text { economy. Panel estimation methodology is used } \\
\text { two datasets of total } 52 \text { economies for the perio } \\
\text { from } 1990 \text { to } 2014 \text {. The dataset were consist } \\
\text { developed economies and } 24 \text { developing economi } \\
\text { conductance of a comparative analysis of whether } \\
\text { fiscal decentralization on corruption remains } \\
\text { developed and developing economies or varies wi }\end{array}$ \\
\hline u.e & $\begin{array}{l}\text { study indicate that fiscal decentralization has an adverse effect } \\
\text { on corruption in developing economies. While, fiscal } \\
\text { decentralization contributes positively in reduction of } \\
\text { corruption in developed economies. }\end{array}$ \\
\hline
\end{tabular}

\section{Introduction}

Fiscal decentralisation can be defined as a two-dimensional policy formation that incorporates two tools. The first tool is the decentralisation of tax collection, where local governments are given authority to administer tax collection. The second tool is the decentralisation of tax expenditure, where local governments are responsible for forming policies utilising the budget at their discretion.

It can be ranked, based on task transmission and the level of sovereignty endowed to the district establishments. Actions of fiscal decentralisation may be as (a) Revenue and (b) expenditures. On behalf of experimental commitments, fiscal 
decentralisation can be, separately, determined by way of; district regime revenues out of over-all regime revenues in a jurisdiction or by the district regime spending out of total regime spending in the jurisdiction. However, the consideration must be taken into account that the correct estimation of the degree of decentralisation should only include the aspects that can be decentralised while ignoring general public needs such as social security and defence.

The term 'decentralisation, can mean certain different things to different individuals. In the present analysis, decentralisation refers to handing over central authority and resources from the central government to the lower levels of government. There are many levels of government at a disaggregated geographical level in a decentralised system (Kolstad et al.,2014), Rodden, 2004).

Various aspects of decentralisation can be identified. Generally, decentralisation is discussed in three important dimensions, which are: administrative, political and fiscal. Administrative decentralisation talks about the authority of local governments to recruit civil servants at the local level or to terminate them. It can also refer to the government structure where local governments are provided with resources to enforce the central policies. However, they have no role in policy formation. Political decentralisation describes the system of governance in which directly elected local governments are given certain powers and authorities at lower levels to provide services to the public. Fiscal decentralisation refers to the local government's authority to impose taxes on citizens and firms and decide how these taxes will be utilised through local budgets (Kolstad et al., 2014).

Although every state has its distinctive issues to be addressed through decentralisation, some common elements are behind the uprising trend of decentralisation. One of these elements is that the central authorities encourage corruption and the downward system of power devolution is one way to limit corrupt practices. This idea has pledged decentralisation as an essential part of donors backed anti-corruption policies in developing economies. The reforms related to decentralisation have a crucial role in initiatives like the World Bank's anti-corruption narrative (Fjeldstad, 2004;Lessmann and Markwardt, 2010).

Decentralisation alone cannot be a solution to the problems. Local authorities must have the capacity to decide for decentralisation to happen effectively. In other words, decentralisation can be effective only when an extensive amount of tasks and authority is allocated to the local bodies' financial resources to match these responsibilities Bahl, (1999a). Moreover, the process of decentralisation is a complicated one and requires an accurate implementation to get any benefits from it (Bahl, 1999b).

According to the World Bank, Corruption can be described as; "the abuse of public or corporate office for private gain"Bhargava, (2005).The stated definition is quite simple, yet it comprehensively covers major aspects of corruption in public 
sectors. The state institutions are run by many elected officials and bureaucrats who, sometimes, can get themselves involved in certain corrupt practices like nepotism, bribery, extortion or embezzlement Admundsen, (2000). Corruption can occur at any stage of financial management, i.e., revenue collection, expenditures management or indirect financial dealings like the formation and imposition of rules and regulation (Martinez et al.,2007).

There can be mass scale corruption, generally done by high-level officers, or small level corruption practised by lower-level officials. Corruption can be systematic and structured in the form of an organised group or unsystematic and disorganised(Celentani \& Ganuza, 2002); Waller et al., 2002).

The experimental studies in fiscal decentralisation and corruption produce argumentative and controversial results. Some studies demonstrate that decentralisation increases corruption (Treisman, 2000); (Fan et al., 2009). In contrast, other studies state that decentralisation helps decrease corruption and maintain good governance (De Mello \& Barenstein, 2001).

The main objective of the study is to examine the impact of fiscal decentralisation on the prevalence of corruption in the economy. This study will also conduct a comparative analysis of whether the impact of fiscal decentralisation on corruption remains the same in developed and developed economies or varies with the change in the level of development of the economies. Using a panel data set of 52 economies (including 28 developed economies and 24 developing economies) from 1990 to 2014, we carry out panel estimation techniques of Fixed Effect and Random Effect.

Comparative analysis of both developed and developing economies is a significant contribution of this study. There is no such study on both developed and developing economies to the best of knowledge. Previous literature have discussed either selected economies or a single country, and some studies have conferred about the developing economies in the aspect of corruption and decentralisation. The present study supports the view that the ongoing tendency towards more decentralisation can be explained based on the greater scope of government officials' accountability, which this system of governance provides. Decentralisation can make such an environment in which the government officers can directly witness the effects of their corrupt activities on the public,which they have to deal with. The overall outcome is that decentralisation can decrease corruption, increase investment, and accelerate economic development.

\section{Literature review}

This section analyses the theoretical and empirical literature associated with decentralisation and corruption. 


\section{Theoretical Literature}

When corruption is mentioned in connection to decentralisation and hierarchal organisation of government, the emphasis is generally on grand corruption. Several theoretical opinions have surfaced to explain the question of whether decentralisation causes a decrease in corruption or increases in it. These different directions of reasoning are discussed below.

The arguments of (Tiebout 1956) were based on competition logic. He asserted that decentralisation helps in realising different individual demands. He argued that the decentralisation brought competition between various sub jurisdictions and provided each jurisdiction with a chance to introduce its distinctive services and taxation system.

Following this competition logic, other political economists argued that the competition between local administrations for capital, labour and other production factors compelled the local officials to decrease the corruption. The officials who may mismanage the resources or plunge themselves into corruption will eventually lose their business and public support to other jurisdictions. It will cause a decline in the tax base of that government. In this way, competition between various jurisdictions might regulate the local governments and help in reducing corruption in government (Shleifer and Vishny, 1993); Weingast, 1995); Arikan, 2004).

On the other hand, some scholars claimed that competition between jurisdictions could contribute to increase corruption. The tug of war between local governments might become counterproductive and lead to a race to the lowest level, which will negatively impact the governance and level of corruption (Keen \&Marchand, 1997).

Another set of arguments about the relationship between corruption and decentralisation was that decentralisation affects accountability, which is the ability to make the government official answerable for their acts. Decentralisation brought the citizens and government closer to each other, and some scholars argued that this proximity encouraged accountability and minimised corruption. In contrast, others said that it rather hindered the accountability process and supported corruption.

Those who advocated the first argument, decentralisation encourages accountability, assumed that the nearness between government and community made the residents acquire the information about the government attitude. This discourages negative practices which confined the chances of rent-seeking in the governments. The smaller size of local communities also made the citizen realise who was answerable for the policies and application. This small size also helped the citizens keep a check on government officials' performanceFan et al.,(2009). 
Some scholars offered a counter-argument to the notion that decentralisation increases accountability. (Tanzi, 1995)claimed that the idea of decentralisation bringing accountability was hollow. He contended that decentralisation brought the administration in too close connection with the public. This close contact might support favouritism, resulting in corruption as the officials get more focused on the personal needs of individuals than the general interest of the public.

\section{Empirical Literature}

Treisman, (2000) found that the economies with a decentralised system of governance have a higher level of corruption. For this purpose, he used a dummy variable to analyse federal states. A state would be deemed federal if it has subnational governments having constitutionally designated authority. This dummy variable for the federal government used by Treisman might not indicate the level of decentralisation. For him, decentralisation and the federal government system are different things. By analysing the cross-country data he concluded that the perception of corruption is greater in the economies with decentralised governments. At the same time, the provision of services and performance is poorer in these economies.

Fisman and Gatti, (2002) found a strong association between the lower level of corruption and fiscal decentralisation by analysing the data of fifty-five states. The civil liberties level, the GDP, population, the proportion of government's expenses in GDP, ethnic fractionalisation, openness, contract enforceability index, and the federal states' dummy variable were used in this analysis. To measure the corruption, they utilised the corruption index by ICRG, which is centred on evaluating potential risk encountered by private foreign investors because of the corruption in the host states. It is one of the most widely used scales to measure corruption in empirical researches.

Ledermanet al.,(2005) argued that different kinds of decentralised systems had a different impact on corruption. The findings indicated that with a strong democratic, parliamentary system, political stability and free press, the tendency of corruption had a decline. These results were constant with diverse sets of controls, excluding free media, which is influenced by the impact of economic development and growth on corruption. Further findings of his study indicate the role of political institutions in defining the frequency of corrupt practices.

Fan et al., (2009)used cross-section data of 80 states examined that in the economies with more administrative or governance levels and a greater number of officials working at the local levels, bribery is more prevalent. Unlike the other research studies, which based their results on perceived data, this research used the empirical data collected from the World Bank Economic Survey of Bribery. Similar literature stressed the effect of the federal government system on corruption.Goldsmith, (1999); Kunicova and Rose-Ackerman, (2005)all had 
concluded that the federal government system was linked with the higher levels of perceived and practised corruption.

Karlström, (2015) analysed the role of the level of democracy to determine the association between corruption and decentralisation. He found out that the effectiveness of decentralisation to curb corruption depended on the institutions that provided information to the citizens on government attitude and the ability to work upon the provided information. Therefore, he suggested that decentralisation could restrict corrupt practices in democratic states but not in autocratic states where such institutions did not exist. Many indicators for decentralisation in crosssectional regression with nearly 72 states were taken as a sample. The acquired data supported the conditional impact of democracy on the link between corruption and decentralisation. He asserted that administrative and fiscal decentralisation is linked with lower levels of corruption in democratic states while higher levels in authoritarian states.

\section{Material and Methods}

\section{Theoretical Framework}

This section uses a modified version of the rent-seeking model (Edwards and Keen, (1996);Arikan,(2004)carries out a comparative statistic to show the effect of greater decentralisation on the level of corruption. Fiscal decentralisation means: as the number of jurisdictions increases, the extent of decentralisation rises. Empirical studies by [Oates, (1985); Nelson, (1987); Eberts and Gronberg, (1988); Forbes and Zampelli, (1989) andZax, (1989)] have used the same definition for decentralisation variable. For instance, to evaluate the level of decentralisation, they used the total number of local government units in a state, metropolitan or county area.

The present study comprises of two datasets of total 52 economies for the period of 24 years from 1990 to 2014. The datasets are based upon 28 developed economies and 24 developing economies. The selection of 52 economies is based on the availability of data (List is attached in Appendix).

\section{Econometric Specification}

In the light of above discussion, Two models are tested to examine the relationship we now propose the following two models for estimation of study. First model explores the relationship between fiscal decentralisation and corruption in developed economies. While, second model explores the relationship between fiscal decentralisation and corruption in developing economies. 


\section{Model 1 (Developed Economies)}

$$
\begin{aligned}
& \operatorname{Corr}_{i t}=\alpha_{o}+\alpha_{1} F D_{i t}+\alpha_{2} D E M O_{i t}+\alpha_{3} O P E N_{i t}+\alpha_{4} \ln P O P_{i t}+\alpha_{5} E L_{i t}+ \\
& \alpha_{6} W P_{i t}+\quad \alpha_{7} G O V T_{i t}+\alpha_{8} \ln G D P_{i t}+\alpha_{9} R L_{i t}+\alpha_{10} G E_{i t}+\alpha_{11} R Q_{i t}+ \\
& \alpha_{12} P S V_{i t}+\alpha_{13} V A_{i t}+\mu_{i t}(\mathrm{i})
\end{aligned}
$$

Model 2 (Developing Economies)

$$
\begin{aligned}
& \operatorname{Corr}_{i t}=\beta_{o}+\beta_{1} F D_{i t}+\beta_{2} D E M O_{i t}+\beta_{3} O P E N_{i t}+\beta_{4} \ln P O P_{i t}+\beta_{5} E L_{i t}+ \\
& \beta_{6} W P_{i t}+\quad \beta_{7} G O V T_{i t}+\beta_{8} L N G D P_{i t}+\beta_{9} R L_{i t}+\beta_{10} G E_{i t}+\beta_{11} R Q_{i t}+ \\
& \beta_{12} P S V_{i t}+\beta_{13} V A_{i t}+\mu_{i t} \quad \text { (ii) }
\end{aligned}
$$

Notations used in the above equations are defined as,

Corr $=$ Corruption index, $F D=$ Fiscal Decentralisation, $D E M O=$ Democracy, $O P E N=$ Trade Openness, $\ln P O P=$ Population Size, $E L=$ Education Level, $W P=$ Women in Parliament, GOVT= Government Size, $\ln G D P=$ Per Capita GDP, $R L=$ Rule of Law, GE= Government Effectiveness, $R Q=$ Regulatory Quality, $P S V=$ Political Stability \&Absence of Violence $(P S V)$ and $V A=$ Voice \& Accountability.

\section{Data Sources}

\section{Dependent Variable}

The data of the dependent variable (Corruption Index) is collected from

\section{International Country Risk Guide (ICRG).}

\section{Independent Variables}

Data of independent variable, Fiscal Decentralisation is collected from the International Monetary Fund's Government Finance Statistics (GFS). Whiledata of Trade openness, Population Size, Education Level, Women in Parliament and Per Capita GDP is collected from Worldwide Development Indicators (WDI). Data on Governance Indicators (Rule of Law, Government Effectiveness, Regulatory Quality, Political Stability, Voice \& Accountability and Democracy) is collected from Worldwide Governance Indicators (WGI) except Democracy whose data is gathered from International Country Risk Guide (ICRG).

\section{Estimation Methodology}

As our data is panel in nature, For this purpose panel estimation technique is required for above mentioned models. In order to achieve fundamental objectives of the study the most suitable method in such manner is the utilization of Fixed Effect and Random Effect model. But before moving towards Fixed Effect and Random Effect Modelingestimation, first of all, we apply Pooled OLS. Pooled OLS estimation is rejected because of heterogeneity in both models. This is carried 
out with the help of Breusch \& Pegan (B\&P) Lagragian test. After Pooled OLS, we move towards Random Effect Model and Fixed Effect Model.

As far as random effect model is concerned, we assume that time and country specific special effects are distributed randomly and that the parametric function differs from country to country. At this point, our 52 economies have a shared mean value for the intercept. Contrary to the fixed effects model, we assume that the non-observable country specific special effects, time specific effect and stochastic disturbance term, all are identical, individualistic, and independent and also distributed with zero mean and constant variance. When these assumptions hold, the random effect model produces constant and more effective assessments than that of Fixed effect model. For analyzing the impact of those variables which does not change with the time fixed effect model is better used. With this model the biasing effect of time invariant variables have been controlled for achieving the best impact of varying variables.

After Performing Random Effect and Fixed Effect Modeling, Hausman test is applied in order to find out which model is most appropriate for further analysis whether Random Effect or Fixed Effect. If we get statistically significant p-values, we intend to use Fixed effect model. If not, then we use Random effect model. This means if the p-value is less than $5 \%$ we will reject null hypothesis $\left(\mathrm{H}_{0}\right)$ and agree to take alternative hypothesis $\left(\mathrm{H}_{1}\right)$. but then again if the $\mathrm{p}$-value is more than $5 \%$ we will not reject null hypothesis $\left(\mathrm{H}_{0}\right)$ It means that we will use Random effect model as an appropriate model. If the p-value is significant, it will show that, our model is good and fitted well. In our analysis of this study Hausman test suggested Fixed Effect Model for Developed Economies and Random Effect Model for Developing Economies.

\section{Results and Discussion}

Regression results of model 1 (Developed Economies) and model 2 (Developing Economies) will be discussed in this section one by one.

Table 1

Estimation Results

\begin{tabular}{ccc}
\hline Variables & $\begin{array}{c}\text { Model 1 } \\
\text { (Fixed Effect Model ) }\end{array}$ & $\begin{array}{c}\text { Model 2 } \\
\text { (Random Effect Model) }\end{array}$ \\
\hline \multirow{2}{*}{ FD } & $-2.93025^{* * *}$ & $1.512746^{* * *}$ \\
$(1.019)$ & $(0.558)$ \\
\hline \multirow{2}{*}{ DEMO } & $0.3833809^{* * *}$ & 0.0500264 \\
& $(0.108)$ & $(0.0504)$ \\
\hline \multirow{2}{*}{ OPEN } & -0.0029576 & $-0.0093071^{* * *}$ \\
& $(0.002)$ & $(0.0021)$ \\
\hline \multirow{2}{*}{ EL } & 0.0004334 & $-0.0136839^{* * *}$ \\
& $(0.003)$ & $(0.005)$ \\
\hline
\end{tabular}




\begin{tabular}{ccc}
\hline \multirow{2}{*}{ WP } & $0.0189738^{* * *}$ & $-0.0120044^{* *}$ \\
& $(0.008)$ & $(0.006)$ \\
\hline \multirow{2}{*}{ GOVT } & $-0.0708721^{* * *}$ & 0.0101132 \\
& $(0.022)$ & $(0.017)$ \\
\hline \multirow{2}{*}{$\ln$ POP } & 0.8817511 & $-0.2145618^{* * *}$ \\
& $(0.744)$ & $(0.084)$ \\
\hline \multirow{2}{*}{$\ln$ GDPPC } & $-1.508752^{* * *}$ & $0.2683279^{* *}$ \\
& $(0.374)$ & $(0.154)$ \\
\hline \multirow{2}{*}{ GE } & -0.2219611 & $(0.339425$ \\
& $(0.187)$ & 0.0610908 \\
\multirow{2}{*}{ PSV } & 0.1611718 & $(0.124)$ \\
\hline \multirow{2}{*}{ RQ } & $(0.134)$ & -0.2479573 \\
& -0.2500831 & $(0.188)$ \\
\multirow{2}{*}{ RL } & $(0.19)$ & $0.3471158^{*}$ \\
& $0.9544715^{* * *}$ & $(0.217)$ \\
\hline \multirow{2}{*}{ VA } & $(0.296)$ & -0.0319768 \\
& -0.3622753 & $(0.168)$ \\
\hline \multirow{2}{*}{ CONS } & $(0.292)$ & $5.376139^{* * *}$ \\
& 5.160898 & $(1.441)$ \\
\hline
\end{tabular}

Note: Thep-value of coefficient is given in parentheses, ${ }^{* * *},{ }^{* *},{ }^{*}$ shows that variable is significant at $1 \%$ level, $5 \%$ level and $10 \%$ level respectively. The values in brackets are Standard error values.

\section{Results of Model 1}

According to the regression results of model 1, fiscal decentralisation and corruption in developed economies show that the analysis is statistically significant at 0.000 level. According to Hausman test results, the Fixed Effect model is appropriate for this analysis. Results show that there is a negative and considerable connection between fiscal decentralisation with corruption. It means that fiscal decentralisation has reduced corruption in developed economies and is statistically significant at $1 \%$ level. The change in corruption level regarding fiscal decentralisation is -2.93 . If fiscal decentralisation increases by $1 \%$, then on average, corruption will reduce by $-2.93 \%$ level. This result is similar to the results of Huther and Shah, (1998); Fisman and Gatti, (2002); Altunbas and Thornton, (2012), which reveal that decentralisation plays an over-all effective role in improving governance and in particular, it also reduces the corruption.

The effect of Democracy on corruption is positive and statistically significant at $1 \%$ level. This relationship shows that the higher the democracy level in a country, the higher the level of corruption in developed economies. The change in corruption level because of democracy is 0.38 , which means that if democracy increases by $1 \%$, then on average, the corruption will increase by $0.38 \%$. The result is not consistent with the findings ofGraf, (2005)and Enste and Heldman, (2017), 
according to which increase in democracy in a country should decrease in the level of corruption in that country. The same results have been observed for developed or developing economies. This is because the institutions are also not fully functional in developed countries, which is why, with the rising democracy, corruption will also rise.

The connection between Per Capita GDP and corruption is negative and statistically significant at $1 \%$ level, which shows that the countries' higher real per capita GDP reduces the corruption level in developed economies. The change in corruption level because of GDP Per Capita is -1.50, which means that if the GDP per Capita increases by $1 \%$, then on average, the risk of corruption will reduce by $1.50 \%$. The findings are consistent with the study of Karlström, (2015), that wealthier and developed economies are less corrupted.

The relationship between Women in Parliament and corruption is statistically significant at $1 \%$ level. It reveals that more participation of women in national parliaments is related to higher corruption levels. The change in corruption level due to Women in Parliament is 0.018 , it means that if the WP increases by $1 \%$, then on average, the risk of corruption will increase by $0.018 \%$ level. Our results for developed economies are reverse from the studies of Frank and Schulze, (2000) and Dollar et al., (2001). This may be because, in developed economies, women and men have equal opportunities, and the competition is high for both at equal levels in the national assembly. Therefore, the corruption rate become higher as women participation increases.

The association between Government Size and corruption is negative and statistically significant at the $1 \%$ level, which shows that the countries' higher government size reduces the corruption level in developed economies. The change in corruption level because of Government Size is -0.071, it means that if the Government Size increases by $1 \%$, then on average, the risk of corruption will reduce by $0.071 \%$. Our results support one of the prospective of Kotera et al., (2010) that a larger government with its bigger budget for the enforcement of the law will effectively reduce corruption. Trade openness, Education level and Population Size have no statistically significant effect on corruption level.

The Governance indicators, Rule of Law is positive and statistically significant at $1 \%$ level. It shows that rule of law in developed economies is associated with higher corruption level. The study of Leff,(1964)indicates that a weak rule of law is linked with a higher level of corruption. The change in corruption level due to Rule of Law is 0.95, it means that if the Rule of Law increases by $1 \%$, then on average, the risk of corruption will rise by $0.95 \%$ level. Other indicators of governance like Government Effectiveness, Political Stability and Absence of Violence, Regulatory Quality, Voice and Accountability are insignificant in our analysis. 


\section{Results of Model 2}

Results of model 2 demonstrate that the analysis of Fiscal Decentralisation and corruption in developing economies is statistically significant at the 0.000 level. Results show a positive and statistically significant association of fiscal decentralisation with the corruption and are significant at $1 \%$ level. The change in corruption level about fiscal decentralisation is 1.51. It can be argued that if fiscal decentralisation increases by $1 \%$, then on average, corruption will increase by 1.51 $\%$. These results are similar to the results of Treisman,(2000); Fan et al., (2009). The result of the study support the concept of accountability theory that as the small jurisdiction will get more focused towards their personal needs rather than the general interest of the public, corruption will increase. Moreover, another reason for this is the close connections between small level government and the public could also establish corruption networks.

The linkage between corruption and Trade Openness is negative and statistically significant at $1 \%$ level. It means that trade openness leads to lower corruption. The result is similar to the results of Fisman and Gatti, (2002)\&Pellegrini and Gerlagh, (2004). The change in corruption level due to trade openness is 0.009 . This means that if the trade openness increases by $1 \%$, then corruption will be reduced by $0.009 \%$ on average. This relation shows that as the restrictions in developing economies for imports and exports quota and tariffs become tighter, the economies will tend towards high-risk corruption. While, with the low imports restrictions and trade openness, corruption will reduceEnste and Heldman, (2017).

GDP Per Capita and Corruption are positively associated with each other and are statistically significant at 5\% level. It reveals that developing economies with higher GDP have more chances of corruption. The change in corruption level because of GDP Per Capita is 0.26, which means that if the GDP Per Capita increase by $1 \%$, then on average, the risk of corruption will increase by $0.26 \%$. The previous studies have also been unable to explain the main reasons behind this relationship: as the GDP increases, corruption will increase. According to Aidt, (2011), the policy measures in developing economies should target in reducing corruption. Through this, a protected and preserve capital base can be established within a country essential for sustainable growth.

The sign of size of the country in terms of Population Size is negative and statistically significant at $1 \%$ level. The change in corruption level because of Population Size is -0.21 . If the Population Size increases by $1 \%$, then the risk of corruption reduces by $0.21 \%$ on average. The empirical results of this study's developing economies are opposing the theory that as the population size increases, corruption increases. This shows that having a large population in a country may lead to less corruption if the government officials are honestly fulfilling their duties Knack and Azfar, (2003). 
The Education Level and Women in Parliament are statistically significant at $1 \%$ and $5 \%$ level respectively and negatively affect the level of corruption. This shows that $1 \%$ increase in Education Level will reduce corruption by $0.01 \%$ and $1 \%$ increase in Women in Parliament and reduce corruption by $0.01 \%$. The coefficient of Education Level describes that higher education levels in a country make it less inclined towards corruption. Higher education improves citizens' ability to judge better the politician's performance and control government's activities Ali and Isse, (2002). In comparison, the previous studies have focused on the number of women in national assembly's in developing economies and found that more participation of women in national parliament is related to lower corruption levels than men in national assembly's or those positions. Therefore, women are less inclined towards corruption than men (Dollar et al., 2001).

The Government Size and democracy have no statistically significant effect on corruption level. The Governance indicator, Political Stability and Absence of Violence, Government Effectiveness, Voice and Accountability and Regulatory Quality are not statistically significant in the present analysis of Developing Economies; only the Rule of Law is statistically significant at $10 \%$ level. The rule of law has a positive effect on corruption, which means that rule of law in developing economies is associated with a higher level of corruption. These results are consistent with the study of Huntington,(1968). According to that study, weak rule of law is associated with a higher level of corruption. The variation in corruption because of Rule of Law is 0.34. It shows that a one percent increase in Rule of Law on average will bring $0.34 \%$ increase in corruption level.

\section{Conclusion}

The results of the study indicate that fiscal decentralisation has an adverse effect on corruption in developing economies. While, fiscal decentralisation contributes positively in reduction of corruption in developed economies. We can conclude from findings of this study that fiscal decentralisation of the developing economies cannot control the corruption because of weak institutional control, bad governance which is already prevailing in the society. More authority in hands of already people corrupt them more. Fiscal decentralization provides more chances to already corrupt people. However, in the case of developed economies, presence of strong institutional setup and prevalence of good governance in the economy further strengthened and reinforced by decentralization.

According to the estimated results, developing economies seem to become more corrupted with fiscal decentralisation than developed economies. Decentralisation appeared earlier in developed economies; therefore, corruption is much less in contrast to developing economies, where decentralisation occurred later. When fiscal decentralisation is used as an instrument of government reform, it enhances government effectiveness and lessens corruption, as stated in the theory of fiscal federalism. Such policies might be acceptable for public reform in developed economies but might be highly damaging to the developing world 
Kwon, (2013). Regarding the literature, developed economies are considered more decentralised than developing economies, as the historical experience of developed economies strongly distinct from what we observe in developing economies' today Gadenne and Singhal, (2014).

\section{Policy Recommendations}

The results of the study recommends that,

- Public policy of the developing economies must be designed in such a way that the institutional infrastructure and governance level must be supportive to the decentralization policy.

- Continuity of the local governments can further strengthen the process of fiscal decentralisation.

- Reformation in policies can lessen the motives for corruption such as; down-toning regulations, provision of tax incentives and making the system of taxation as transparent and open as possible. 


\section{References}

Admundsen, I. (2000). Corruption: Definitions and concepts. Chr. Michelsen Institute Working Paper.

Aidt, T. S. (2011). Corruption and sustainable development. International Handbook on the economics of corruption, 2, 3-51.

Ali, A. M., \& Isse, H. S. (2002). Determinants of economic corruption: a crosscountry comparison. Cato J., 22, 449.

Altunbaş, Y., \& Thornton, J. (2012). Fiscal decentralisation and governance. Public Finance Review, 40(1), 66-85.

Arikan, G. G. (2004). Fiscal decentralisation: A remedy for corruption? International Tax and Public Finance, 11(2), 175-195.

Bahl, R. (1999a). Fiscal decentralisation as development policy. Public Budgeting $\mathcal{E}$ Finance, 19(2), 59-75.

Bahl, R. (1999b). Implementation rules for fiscal decentralisation. International Studies Program Working Paper, 30.

Bhargava, V. (2005). The Cancer of corruption. Paper presented at the World bank global issues seminar series.

Celentani, M., \& Ganuza, J.-J. (2002). Corruption and competition in procurement. European Economic Review, 46(7), 1273-1303.

Crook, R., \& Manor, J. (2000). Democratic decentralisation.

De Mello, L. R., \& Barenstein, M. (2001). Fiscal decentralisation and governance: a cross-country analysis.

Dollar, D., Fisman, R., \& Gatti, R. (2001). Are women really the "fairer" sex? corruption and women in government. Journal of Economic Behavior $\mathcal{E}$ Organization, 46(4), 423-429.

Eberts, R. W., \& Gronberg, T. J. (1988). Can competition among local governments constrain government spending? Economic Review(QI), 2-9.

Edwards, J., \& Keen, M. (1996). Tax competition and Leviathan. European Economic Review, 40(1), 113-134.

Enste, D., \& Heldman, C. (2017). Causes and consequences of corruption: An overview of empirical results: IW-Report. 
Fan, C. S., Lin, C., \& Treisman, D. (2009). Political decentralisation and corruption: Evidence from around the world. Journal of Public Economics, 93(1), 14-34.

Fisman, R., \& Gatti, R. (2002). Decentralisation and corruption: evidence across countries. Journal of Public Economics, 83(3), 325-345.

Fjeldstad, O.-H. (2004). Decentralisation and corruption. A review of the literature: Chr. Michelsen Institute.

Forbes, K. F., \& Zampelli, E. M. (1989). Is Leviathan a mythical beast? The American Economic Review, 79(3), 568-577.

Frank, B., \& Schulze, G. G. (2000). Deterrence versus intrinsic motivation: experimental evidence on the determinants of corruptibility. Paper presented at the Econometric Society World Congress 2000 Contributedod Papers.

Gadenne, L., \& Singhal, M. (2014). Decentralisation in developing economies. Annu. Rev. Econ., 6(1), 581-604.

Goldsmith, A. A. (1999). Slapping the grasping hand. American Journal of Economics and Sociology, 58(4), 865-883.

Graf Lambsdorff, J. (2005). Consequences and causes of corruption: What do we know from a cross-section of countries? : Passauer Diskussionspapiere: Volkswirtschaftliche Reihe.

Huntington, S. (1968). Political Order in Changing Societies, New Haven, CT, Yale University Press.

Huther, J., \& Shah, A. (1998). Applying a simple measure of good governance to the debate on fiscal decentralisation (Vol. 1894): World Bank Publications.

Keen, M., \& Marchand, M. (1997). Fiscal competition and the pattern of public spending. Journal of Public Economics, 66(1), 33-53.

Knack, S., \& Azfar, O. (2003). Trade intensity, country size and corruption. Economics of Governance, 4(1), 1-18.

Kolstad, I., Wiig, A., \& Somville, V. (2014). Devolutionary delusions? The effect of decentralisation on corruption. CMI Working Paper.

Kotera, G., Okada, K., \& Samreth, S. (2010). A study on the relationship between corruption and government size: the role of democracy.

Kunicova, J., \& Rose-Ackerman, S. (2005). Electoral rules and constitutional structures as constraints on corruption. British Journal of Political Science, 35(4), 573-606. 
Kwon, O. (2013). Fiscal decentralisation: An effective tool for government reform? Public Administration, 91(3), 544-560.

Lederman, D., Loayza, N. V., \& Soares, R. R. (2005). Accountability and corruption: Political institutions matter. Economics \& Politics, 17(1), 1-35.

Leff, N. H. (1964). Economic development through bureaucratic corruption. American behavioral scientist, 8(3), 8-14.

Lessmann, C., \& Markwardt, G. (2010). One size fits all? Decentralisation, corruption, and the monitoring of bureaucrats. World Development, 38(4), 631646.

Martinez-Vazquez, J., Boex, J., \& Arze del Granado, J. (2007). Fighting corruption in the public sector: Emerald Group Publishing Limited.

Nelson, M. A. (1987). Searching for Leviathan: Comment and extension. The American Economic Review, 77(1), 198-204.

Oates, W. E. (1985). Searching for Leviathan: An empirical study. The American Economic Review, 75(4), 748-757.

Pellegrini, L., \& Gerlagh, R. (2004). Corruption's effect on growth and its transmission channels. Kyklos, 57(3), 429-456.

Shleifer, A., \& Vishny, R. W. (1993). Corruption. The quarterly journal of economics, 108(3), 599-617.

Tanzi, V. (1995). Fiscal Federalism and Decentralization: A Review of Some Efficiency and.

Tiebout, C. M. (1956). A pure theory of local expenditures. Journal of Political Economy, 64(5), 416-424.

Treisman, D. (2000). The causes of corruption: a cross-national study. Journal of Public Economics, 76(3), 399-457.

Waller, C. J., Verdier, T., \& Gardner, R. (2002). Corruption: top down or bottom up? Economic Inquiry, 40(4), 688-703.

Weingast, B. R. (1995). The economic role of political institutions: Marketpreserving federalism and economic development. Journal of Law, Economics, $\mathcal{E}$ Organization, 1-31.

Zax, J. S. (1989). Is there a Leviathan in your neighborhood? The American Economic Review, 79(3), 560-567. 
